\title{
Food Security and Its Response to Livelihood Diversification in Pastoral Area of Ethiopia; A Review
}

\author{
Gebre Garmame* \\ Department of Horticulture, Bule Hora University, PO box 144, Bule Hora, Ethiopia \\ Ashebir Nega \\ Department of Rural Development and Agricultural extension, Bule Hora University \\ PO box 144, Bule Hora, Ethiopia \\ Tadese Jilo \\ Department of plant sciences, Bule Hora University, PO box 144, Bule Hora, Ethiopia
}

\begin{abstract}
In Ethiopia, Pastoralists represent approximately $10 \%$ percent of the country population, and approximately $40 \%$ of the land area of Ethiopia is considered to be under pastoral production system. Consequently, Pastoralists contribute a significant amount to the national economy. However, the pastoral production system and in particular the food security and livelihood situation is highly threatened due to various factors. This review is, therefore, shows the definition and concepts of food security and livelihood diversification. Besides, it elaborate factors affecting food security and effect of livelihood diversification on food security in pastoral area of Ethiopia. Methodologically, this manuscript is based on intensive literature review of published materials such as books, articles and extra scholar materials. It was displayed that household head sex, family size, age of household head, educational level of household head, crop production and agricultural technology (use of chemical fertilizer and pesticides, improved seeds), livestock ownership and number, dependency ratio, distance from market center, access to credit and developmental agents visit had found to be significant in determining household food security. Livelihood diversification basically influenced by push and pull factors. In general, higher the level of the household livelihood diversification, results with, the more food secure of the households. In the future, concerned agents should focus on boosting educational level, family planning and awareness creation to reduce dependency ratio, credit serves and visit by development agents for livelihood diversification and thereby food security.
\end{abstract}

Keywords: Ethiopia, Factors, Food security, Livelihood diversification and Pastoral area

DOI: $10.7176 / \mathrm{FSQM} / 98-01$

Publication date:June $30^{\text {th }} 2020$

\section{Introduction}

About 17 million people in the East Africa region are highly or extremely food insecure and are in need of emergency humanitarian assistance. This is mainly due to the cumulative effects of poor rainfall/droughts in pastoral and marginal cropping areas in the eastern sector of the region, civil insecurity/conflict and consequent population displacement and disruption to markets, undiversified livelihood and high food prices (FEWS NET, 2018). Drought conditions have caused livestock mortality and household asset loss and undermined pastoral household incomes and coping strategies. Livestock loss among pastoral groups, which has been close to $50 \%$ of the more drought susceptible cattle and sheep, in some areas, means that recovery will be a long drawn experience, consequently, most of them have been faced food insecurity (Jebessa and Zelalem, 2014).

In Ethiopia, Pastoralists represent approximately $10 \%$ percent of the country population, and approximately $40 \%$ of the land area of Ethiopia is considered to be under pastoral production system (Amare, 2018). Livestock in the pastoral areas are the major source of food (milk and meat) and income, as well as a source of employment. They also serve similar purposes and functions for people living in urban and rural towns to the pastoral areas. Livestock contribute a significant amount to the national economy. In terms of gross national product, the contribution of livestock to the agriculture sector and the national economy is $40 \%$ and more than $20 \%$ respectively (Beruk, 2003). However, the pastoral production system and in particular the food security and livelihood situation is highly threatened because of different man-made and natural risks. The current scenario shows that pastoral livelihood system is seemingly changing due to factors such as recurrent draught and conflict, and other natural and manmade calamities. A study focusing on the future of pastoralism in Ethiopia reads that pastoral households will continue to diversify their sources of income to include waged employment and agriculture where it is feasible, and trading activities as supplements to livestock-based incomes. The percentage of so called "pure" pastoralists (those who depend on livestock for more than 90 percent or more for their income) will decline, especially in areas where cultivation is possible. According to a study on the Future of Pastoralists in Ethiopia, the pure pastoralists will continue being engaged selectively in cultivation apart from livestock production (Jebessa and Zelalem, 2014).

This scenario leads to agro-pastoralism as an alternative livelihood option for the future of pastoralists. In 
addition, pastoralism will continue to transition toward a model of a fixed base camp/settlement and mobile satellite camp where animals seasonally migrate with mainly young males but part of the family remains sedentary. This strategy allows some family members to trade, work, and/or seek services in small towns and settlements on a part- or full-time basis (Little et al, 2010). The pastoralists, especially in Borana, the number of people leaving the system as dropouts is on the rise; number of qolles and degas increasing (Jebessa And Zelalem, 2014).

Livelihood diversification is a process by which rural households construct a diverse portfolio of activities and social support capabilities in their struggle for survival and improvement in their standards of living. Livelihood diversification can be classified into three namely on farm, nonfarm and off farm. Livelihood diversification basically influenced by a set of factors in both the area of origin as well as the destination. These factors are routinely referred to as "push" and "pull" factors - or those negative factors that "push" a household out of a given area or lifestyle, and those positive factors that "pull" them into a new location. Specifically, there are different factors that determines pastoral livelihood diversification strategies. Those factors are classified into five types of livelihood assets/capitals, namely, human, financial, social, natural, and physical capital.

Mostly, Livelihood diversification and food security are strongly correlated. But, it is not well addressed in pastoral area of Ethiopia. This review is, therefore, focused on the factors affecting food security and effect of livelihood diversification on food security in pastoral area of Ethiopia.

\subsection{Objective}

The main objective of this review study was to display livelihood diversification and food security in pastoral area of Ethiopia.

Specifically, the review is trying:

* To display the factors that determines food security of pastoral areas of Ethiopia;

* To reveal the effect of livelihood diversification on food security of pastoral areas of Ethiopia.

\subsection{Methodology}

This manuscript is based on intensive literature review of published materials such as books, articles and extra scholar materials.

\section{Literature Review}

\subsection{Concepts and Definition of Food Security and Livelihood Diversification}

2.1.1. Concepts and definition of food security

Food security is the opposite of food insecurity. Food insecurity is an evolving concept (Fayisa, 2018). There are many definitions of food insecurity, which is a clear indication of differing views and approaches to the problem (Fayisa, 2018). FAO, defined food insecurity as "a situation that exists when people lack secure access to sufficient amounts of safe and nutritious food for normal growth and development and an active and healthy life" (FAO, 2018). According to this definition, factors that may lead to a situation of food insecurity include non-availability of food lack of access, improper utilization and instability over a certain time period. In other words, food availability, access, stability and utilization form the four pillars of food security. Therefore, the four pillars must be fulfilled simultaneously in order to realize food security objectives.

Food availability refers to the physical presence of food which may come from own production, purchases from internal market or import from overseas. Whereas Food access: household food access is the ability to obtain sufficient food of guaranteed quality and quantity to meet nutritional requirements of all household members. Here, the food should be at right place at the right time and people should have economic freedom or purchasing power to buy adequate and nutritious food. Food access is determined by physical and financial resources, as well as by social and political factors. Access depends normally on income available to the household, the distribution of income within the household, the price of food, access to market; and social and institutional entitlement/rights. Food utilization: This refers to ingestion and digestion of adequate and quality food for maintenance of good health. This means proper biological use of food, requiring a diet that contains sufficient energy and essential nutrients, as well as knowledge of food storage, processing, basic nutrition and child care and illness management (Jrad et al., 2010; USAID, 2008). Stability of food: refers to the continuous supply of adequate food all year round without shortages (Jrad et al., 2010). To be food secure a population, household, or individual must have access to adequate food at all times. The concept of stability can therefore refer to all the availability, access and utilization dimensions of food security.

Food security is, therefore, one of the major world agenda in 2018 in several contexts. Worldwide, in 2017 about 124 million people in 51 countries faced food security crisis (FSIN, 2018). According to FSIN (2018), conflict and insecurity are the major drivers of food insecurity in eighteen countries, and the number of foodinsecure people across the world has been increasing over time. Likewise, food security situation in Ethiopia deteriorated sharply in 2017. In Ethiopia, the number of food-insecure population was increased from 5.6 million in December 2016 to 8.5 million in August 2017 (ACAPS, 2018). An estimated 3.6 million children and women 
in Ethiopia were acutely malnourished in 2017 (IFRC, 2018). The main causes of food insecurity in Ethiopia are prolonged drought, conflict and insecurity, crop disease and other social-economic and political factors. According to FAO (2018), in Ethiopia, prolonged drought conditions are severely affecting the livelihoods in most southern and southeastern pastoral and agro pastoral areas of SNNPR, southern Oromia and southeastern Somali Regions, where cumulative seasonal rainfall was up to 60 percent below average. In these areas, pasture and water availability have declined to extremely low levels, severely affecting crop production and livestock conditions, leading to large scale animal deaths.

Based on duration, food security analysts have classified food insecurity in to two type, which are chronic and transitory (FAO, 2018). Chronic food insecurity is long-term or persistent, and occurs when people are unable to meet their minimum food requirements over a long period of time. Contrarily, transitory food insecurity is shortterm and temporary, and occurs when there is a sudden drop in the ability to produce or access enough food to maintain a good nutritional status. While chronic food insecurity results from extended periods of poverty, lack of assets and inadequate access to productive or financial resources, transitory food insecurity is caused by shortterm shocks and fluctuations in food availability and food access, including year-to-year variations in domestic food production, food prices and household incomes. There is also a concept of seasonal food insecurity which falls between chronic and transitory food insecurity (FAO, 2018). It occurs when there is a cyclical pattern of inadequate availability and access to food. This is associated with seasonal fluctuations in the climate, cropping patterns, work opportunities and disease.

Food security is also an income issue, either in the form of one's own food production or from non-agricultural activities such as employment to access food through the market, livelihood diversification (Dione, 2004). Ethiopia's rural population is highly dependent on both crop and livestock production for their livelihood except pure pastoralist. However, the contribution of agriculture to food security declined as the growth in the food production could not keep pace with the population growth and other factors. The level of food insecurity also increases as to the distinction between transitory and chronic food insecurity has become increasingly blurred (PASDEP, 2005; FAO/WFP, 2012). At national level, food security exists when all people at all times have the physical and economic access to sufficient, safe and nutritious food to meet their dietary needs and food preferences for active and healthy life. At household level, food security implies physical and economic access to food that is adequate in terms of quantity, quality, safety and cultural accessibility to meet each person's need (Ingawa, 2002). Ethiopian government and international donors are implementing different types of responses to food insecurity to attain food self-sufficiency and reduced food aid dependency and to sustain food security (WFP, 2006). Regardless of substantial resources invested each year by the Government and its partners to reduce food insecurity, both chronic and transitory food insecurity problems continued at the household level (European Union, 2012). In fact, the general food security situation has highly deteriorated in different parts of the country particularly in Oromia (Disaster Risk Management and Food Security Sector, 2011). In pastoral area of Oromia region, over $90 \%$ of food supply comes from subsistence rain fed agriculture. Food security situation remain stable in most Oromia region due to good harvest and stable grain food price of 2016. However food security situation becoming volatile in pastoral and agro-pastoral areas of Oromia region due to water and pasture shortage, rising in prices of cereals and drastic fall in livestock price, especially cattle price in drought affected parts in southern Ethiopia resulted in increased request for relief food assistance by the region (WFP, 2017).

Borana semi-arid climatic ecosystem determines two subsistence production systems in the area: Pastoralism and Agro-Pastoralism (Jebessa and Zelalem, 2014). Until recently these two systems were the major source of subsistence and sustainable livelihoods for local community. Viability of this livelihood systems have been undermined by a number of causal factors such as recurrent drought, soaring food prices, conflict, declining natural resources base, reduced mobility, declining livestock terms of trade, HIV/AIDS pandemic, years of economic and political marginalization, breakdown of traditional structures and support systems causing a progressive decline of livestock and deterioration of livelihoods of the community. These endogenous and exogenous factors have posed a great challenge for the food security of pastoral areas and pastoral way of life.

On the other hand, there is a great potential of natural products in Borana which can be developed as an alternative source of income outside livestock. But, the economic potential of certain high-value dry land natural products (honey, gum and incense, Aloe Vera, scent wood \& others ) to improve livelihoods of pastoralists in Borana zone and contribute to the national economy have not been realized. There is limitation in natural products and market diversification and virtually, there is very little value added activities currently practiced by pastoralists. The local prices that wild harvesters/producers are receiving now for these natural products are poor. Herders involved in wild harvesting of natural products in Borana lack the skills, and facilities to produce high quality natural products of interest or value to the world markets. It is not possible to successfully market natural products without well-developed physical and social infrastructures (Jebessa and Zelalem, 2014).

2.1.1.1. Factors affecting food security in pastoral area of Ethiopia

Food insecurity is a reality for hundreds of millions of people around the world, with the most affected countries being those in East Africa. The prevalence of food insecurity varies considerably among different socio-economic 
groups in Ethiopia (Regassa and Stoecker, 2012). In Ethiopia, the problem of food insecurity is exacerbating around pastoral areas due to the influence of a number of socioeconomic and environmental factors. Other study conducted by Ayalneh (2002) in Hitosa, Haramaya, and Merhabete Districts demonstrated that factors that have contributed to transitory and chronic food insecurity in rural Ethiopia are also manifold and varied, ranging from political and socio-economic to environmental. Among the political factors he had listed inappropriate agricultural and marketing polices, and political conflict both at national and local level while demographic characteristics of rural households, inadequate resource endowments, inadequately developed infrastructure such as school, health institution and roads, etc., are among socio-economic factors. According to Sanusi, Badejo, and Yusuf (2006), they indicated that the basic factors influencing the food security status of small-holder farmers or households are the socioeconomic characteristics and resources of individual households. According to Fekadu and Mequanent (2010); Dube et al. (2018), using binary logistic regression model observed that household head sex, family size, age of household head, educational level of household head, on farm/off farm/ non-farm income, use of chemical fertilizer, size of cultivated land, livestock ownership, oxen ownership and soil and water conservation practices were found to be significant in determining household food security. Major of them are elaborated below as follow;

\section{Household head sex}

Head sex of household affects both negatively or positively food security. But, in pastoral area of Ethiopia mostly food security are ensured in male headed household. According to Dube et al. (2018), study conducted at the Shalla District, West Arsi Zone, Oromia Region on determinants of food insecurity and coping strategies of rural households; female headed households had more food insecure which accounted for about a quarter of the total food insecure households or $83.33 \%$ of the total female headed households. Additionally, they revealed that male headed households accounted for about $91.23 \%$ of the total food secure households or $43.33 \%$ of the total male headed households. Thus, Dube et al. (2018), study shown that there are great disparity of food insecurity status due to gender difference among the household heads at one percent probability level. Explanatorily, this could be due to differential access to production resources where male had more access to production resources like cultivated land than females. Besides, Feyisa et al. (2018) also revealed that of female headed households $57 \%$ are food insecure, whereas only $18 \%$ are food insecure for male headed households and the difference $(39 \%)$ is significant at $1 \%$ level of significance. In their study, what we understood is that female headed households are more vulnerable to food insecurity as compared male headed households. This difference is associated with customary rules and practices that often have restrictive effects for women through limiting their access to resources and their roles in food production, preparation, processing, distribution, and marketing activities, which generally negatively affects female headed household food security. Moreover, Indris and Adam (2013) explained that, in view of the strong cultural setting, the social position of men in the pastoral areas is more powerful as compared to women to access social capitals and command over productive resources. Zakari et al. (2014) also found that male-headed households are more food secure compared to female headed households with consisted ideas of justification. According to Bekele et al. (2013), there is also a general accordance among the respondents that females (spouses) are the ones who receive less food and thus suffer most during periods of food shortage.

However, according to Gemechu et al. (2016), study conducted on determinants of farm household food security in Hawi Gudina district, West Hararghe zone, Oromia Regional National State, using binary logistic regression model, household sex headed had no significant effect on food security. This could be indicated that effect of sex headed households might vary from place to place and/ or methodology of the study.

\section{Age of Household Head}

Yusuf (2007) made an assessment of Determinants of Food Security in Pastoral and Sedentary Livelihoods: in the Case of Erer District Shinille Zone, Somali Regional State. Using binary logit model according to his result, age of household head had negative effect on household food security. According to Indris and Adam (2013) study, age of household head had also significant negative effect on food security at 1 percent probability level implying that, an increase in the age of the household head increases the likelihood of the household to be food insecure. Explanatorily, for this would be that, as age of household head gets older, the burden on availability of labour force would increase and the household might have to carry out livestock production and other income generating activities causing vulnerability to food insecurity. Moreover, Dube et al. (2018), revealed that, other variables remaining constant, increased in the age of household head by one year, increased the probability that the household had food insecure by $3 \%$. They reason out the block behind is that, with the small pieces of land supporting the household, as the age of the household head increased, labour force of an individual would fall so as to participate in other different income generating activities which in turn increased exposure of households to food insecurity. While, according to Gemechu et al. (2016) age of household headed had reported no significant effect on food security. 


\section{Family size}

Family size has general implications for household labor resources and consumption. Large family size and polygamy positively affected food security (Bekele et al., 2013). In the context of Borena pastoral societies, family size grow in a subsistence manner for labor and food supply. Herd growth requires a large input of labor possibly leading to an extended family and polygamous marriage, and thus positively affects consumption (Bekele et al., 2013).

However, Gemechu et al. (2016) reported that, the influence of family size on food security of household is negative and significant. The result of their binary logistic regression model revealed that family size measured in Adult Equivalent (AE) had significant at less than one percent probability level. This implies that, as family size increases by one person, the probability of household to be food secure decreases by a factor of 0.248 (Gemechu et al., 2016). According to their explanation, it is due to the households in rural area with large family size mainly composed of nonproductive members could face difficulty in insuring food security due to high burden levied on active labor and less food availability to each person within the household and ultimately end up with difficulty to achieve food security. Besides, Indris and Adam (2013) justified that households with large number of family members might face the probability of food insecurity because of high dependency burden created as a result of sharing available limited resources. By sharing this idea, Dube et al. (2018), stated that, other variables remaining constant, increased in the family size in adult equivalent by a unit, increased the probability that the households had food insecure by $18.4 \%$. They reason out that as family size increased, with limited resources additional family member increased the vulnerability of households to food insecurity by contributing more to consumption than to production. According to Gulled (2006), study on food insecurity and coping strategies of agro-pastoral households in Awbare woreda of Somali Regional State using logistic regression model. His results showed that household size in AE were found to have negatively affect food security status of the households. Also other findings had a consistent idea with like Haile et al. (2005); Asefech and Nigatu (2007) as concluded that large family size reduces the probability of household to be food secured.

\section{Dependency ratio}

According to Hilina (2005) report from Pastoral Areas of Shinile Zone in Somali National Regional State using logistic regression model, dependency ratio had positive association with food insecurity. Similarly, Dube et al. (2018) reported that, dependency ratio had positive and significant relationship at 5\% probability level with the household food insecurity status. According to their study, other variables remaining constant, the probability that the household had food insecure increased by $23.8 \%$ as the dependent age group increased by a unit. This is might be due to the reason that high dependency ratio results in large numbers of dependents in the households with less contribution to production of households which in turn increased risk of food insecurity to the household. Moreover, Indris and Adam (2013) had found dependency ratio to have positive effect at 5 percent probability level in determining the household food insecurity. Having explanation that, the way of life in the pastoral areas promotes large family size which could expose the family to have high dependency ratio and possibly be food insecure than those who have small family size who could have low dependency ratio. But, Gemechu et al. (2016) reported that dependency ratio had no significant effect on food security.

\section{Educational level of household}

Education is foundation for all development. Consequently, Food security and educational deprivation are highly correlated, and they create vicious circle in rural community of many developing countries (DFID, 2005). Recently, Feyisa et al. (2018), reported that illiterate households are more food insecure than literate households, revealing that education contributes to food security especially through influencing productivity. Using longitudinal data analysis, Mutisya et al. (2016) found that the probability of being food insecure decreased by 0.019 for a unit increase in the average years of schooling for a given household. In addition, Dube et al. (2018) hypothesized and conformed that educational attainment by the household head could lead to awareness of the possible advantages of modernizing agriculture by means of technological inputs and diversification of household incomes which, in turn, would enhance household's food supply. Thus, they had reported negative relationship between education level of the household heads and household's food insecurity.

\section{Livestock Ownership and Number of livestock owned}

Livestock ownership plays a key role in contributing to food security through enabling direct access to livestock products, providing cash income from sale of livestock and livestock products for purchasing food, and contributing to increased crop yields as result of improved productivity from the use of manure and traction (Feyisa et al., 2018). Similarly, Indris and Adam (2013) and Dube et al., (2018), revealed that livestock holding had negative and significant relationship with the household food insecurity status. It significantly affected the food insecurity status of households at ten percent probability level. Other variables remaining constant, increased in the number of livestock holding in Tropical livestock unit (TLU), decreased the probability that the household was 
food insecure by $4.5 \%$. Consequently, Dube et al., (2018) revealed that, households with large number of livestock in tropical livestock unit had better chance of earning more income from livestock production. Increase inper capita livestock holdings predicated improved household food security and dietary diversity (Ferro-Luzzi et al. 2001). This in turn helped households to buy foods when they faced shortage and invested for the purchase of farm input which increased production and thus ensuring food security at the household level.

Large herd size certainly contributes to food security through food supply, source of income, as a hedge against risks and as a means of capital accumulation that can be exchanged for food in times of deficit (Doti, 2010). According to Gemechu et al. (2016) study indicated that number of livestock owned had found a significant influence on food security status at less than ten percent probability level and had a positive relationship. Livestock contribute to households' economy in different ways like as a source of pulling power, source of cash income, source of supplementary food and means of transport. Therefore, households with relatively large livestock size had found to be less vulnerable to food insecurity. This implies that the family tends to be food secure when the herd of livestock increases which is supported by studies such as Tesfaye (2003) and Genene and Wegayehu (2010).

\section{Distance from market center}

Access to market and road play a crucial role in achieving global food security by increasing access to food (Feyisa et al., 2018). More importantly, farmers can boost agricultural output productivity and availability through getting access to agricultural input markets, such as improved seed and fertilizer. Besides, they revealed that farmers can increase production if they have access to feasible market for their agricultural outputs. Gemechu et al. (2016) reported that distance from market center has been found to be negatively related with food security and significant at less than five percent probability level. As they had expected, households nearer to market centers had better chances to be food secure than those who are away from market centers due to the reason that households nearer to market center have the probability of selling their produce and purchase food from market easily and timely. In woliso district, households sold their livestock and livestock product to purchase food for family consumption during drought and crop failure problem. According to Gemechu et al. (2016), the odds ratio in favor of food security decrease by 0.340 times if distance in hours of walk increases by one hours keeping other factor constant. In other case, as distance from market center becomes far and far the probability of households to sell their product and purchase supplementary materials becomes less which resulted in low probability of household being food secure (Shiferaw et al., 2003). However, Indris and Adam (2013); Dube et al. (2018) reported that, market distance had no significant effect on food security.

\section{Crop production and agricultural technology}

Pastoral areas are generally marginal to intensive crop production. As a result, livestock production appears to be the most practice and, in some areas the only, option under the existing technologies (Ahmed et al., 2002). However, as a result of challenges (mainly drought and livestock diseases) which have caused rapid deterioration of pastoral livelihoods, pastoralists usually seek out alternative means of survival, at least on transitory basis. Since opportunities are lacking in most pastoral areas, resorting to agriculture is the main option that pastoralists pursue. Indeed, a growing trend toward crop production is now observable in many pastoral areas of Ethiopia (Beruk, 2003). According to Gemechu et al. (2016), cash crop production is one of the explanatory variable which had found to have a significant influence and positive relationship with household food security at less than five percent probability level which implies that the likelihood of food security increases with producing cash crop. Tesfaye (2003) also revealed that cash crop production is positively and strongly associated with higher income, higher rate and intensity of use purchased inputs like fertilizer, improved seed and pesticides and herbicides, and get higher yield, and hence improved food security status of households. Therefore, those households who produce cash crops becomes in a better position than those who did not produce cash crops. Study conducted by Feyisa $e t$ al. (2018) displayed that agricultural technologies, such as fertilizer, improved seed, pesticide and herbicide, significant difference in food security between those who use agricultural technology and who do not use agricultural technology. It has been described that the use of pesticide and herbicide provides economic benefits to the farmers through protection of crop quality and yield; especially it can prevent large crop losses, thus increasing agricultural output and farm income. Likewise, they had indicated that the use of fertilizer had significant effect in achieving of food security. This is due to, yield attributable to fertilizer tends to be much higher in the tropics, which ensures food security. Dube et al., (2018) also reported that the probability that the household had food insecure decreased as the amount of fertilizer used increased. According to their result, other variables remaining constant, increased in the amount of fertilizers applied by one kilogram, decreased the probability that the household had food insecure by $0.3 \%$. Improved seed is also a key input for improving agricultural productivity; thus enhancing household food availability and increasing household income.

\section{Access to credit}

Access to credit is also an important instrument for Household in purchasing modern agricultural technologies 
when the household faces budget deficit. It normalizes consumption at the hard time (Gemechu et al, .2016). Dube et al. (2018) also notes that access to credit refers to the amount of money borrowed from different sources. According to Abebaw (2003), credit for the purpose of consumption or purchase of agricultural inputs like improved seed, chemical fertilizers, etc. improves the food security status (reduce risk of food insecurity) of households. Consequently, different studies shows that households that have access to credit are more food secure than those having limited access to it (Gemechu et al, .2016; Fayisa, 2018).

\section{Development agents' visit}

According to Dube et al. (2018) definition development agents' visit, refers to the frequency that a farmer visited by development agents for technical guidance. They had hypothesized and confirmed that the higher the contact between the farmer and the development agent, the more information and technology flows from the latter to the former which in turn widens the household's knowledge with regard to the use of improved variety and agricultural technologies. Therefore, those farmers with frequent contact are likely to produce more and become food secure than others and thus, reduce risk of food insecurity. In line with Dube et al. (2018) study, Goal Ethiopia (2017) notes that, the frequencies of development agents visit of the farmers and involvement on agriculture plus nonfarm income has positive and significant correlation at $10 \%$ level. According to their analysis the marginal effect predication indicates that, an increase in the frequency of developments agents contact by one day, will lead to raise the probability of agriculture plus non-farm diversification by $4.33 \%$. Due to the information obtained from the extension agents helps rural households to create new income earning mechanism so as to have food secured. 2.1.2. Concepts and definition of livelihood diversification

Livelihood diversification is a process by which rural households construct a diverse portfolio of activities and social support capabilities in their struggle for survival and improvement in their standards of living (Ellis, 2000) and the means of gaining a living (Chambers, 1995). It is recognized as a way to confront the various idiosyncratic risks and shocks that people face (Barrett et al., 2001). It can be defined as the maintenance and continuous alteration of highly varied range of activities and occupations to minimize household income variability, reduce the adverse impacts of seasonality, and provide employment or additional income (Chambers, 1995: Barrett et $a l$., 2001; Kassie et al., 2017).

Livelihood diversification activities are commonly categorized on the bases of their role as mechanism for coping adaptation and accumulation the difference between livelihood diversification of poor household who are struggling for survive and that of better-off household those are for accumulation have been observed (grace, 2000). Like other world, rural people in Ethiopia diversify their asset, income and activity due to push and pull factors. According to study conducted by Goal Ethiopia (2017) revealed that Livelihood diversification basically influenced by a set of factors in both the area of origin as well as the destination. These factors are routinely referred to as "push" and "pull" factors - or those negative factors that "push" a household out of a given area or lifestyle, and those positive factors that "pull" them into a new location. Finding indicate clearly that the most important driver of pastoral area to peri-urban migration is not the "pull" (drought, conflict, livestock diseases, resettlement by local government of the urban centers), it is much more so the "push" (social support system, employment opportunities, education and access to basic services) out of previous pastoral systems.

On the other hands, different scholars categorized livelihood diversification into three namely on farm, nonfarm and off farm. On farm activities are activities, which are directly related with agricultural production focused on both crop production and animal husbandry activities (Ofolsha and Mansingh, 2015; Yizengaw et al., 2015; Asfir, 2016; Addisu, 2017). Nonfarm activities are activities that take place outside the agricultural sector including non-agricultural wage or salary employment and self-employment, rent income, transfers, and remittances (Kassie et al., 2017). Off-farm activities refer to agricultural activities which take place outside the person's own farm agricultural wage or exchange labor and natural resource extraction (mainly charcoal making)( Debele and Desta, 2016; Mengistie and Kidane, 2016; Gecho, 2017).

2.1.2.1. Effect of Livelihood Diversification on Food Security

According to Amare (2018) study, conducted at borena pastoral area, from the income portfolio analysis, the percentage share of the broad livelihood activities indicates that the share of pastoral livelihood alone covers about $64.1 \%$, nonfarm $22.8 \%$ and off-farm $13.1 \%$ in decreasing orders. Further observation of his study revealed that off-farm activities (daily wage, market brokering and environmental gathering) are survival mechanisms pursued mainly by the lower-income groups. The participants' opinion on off-farm livelihood opportunities indicates that engagement with such activity is mostly preferred by (poor pastoralist groups) individuals who do not have herds and those with limited option to construct sustainable (strategic) livelihood diversification. Nonfarm activities, such as rural craft, are also main choice of the poor than their counterparts. Thus, off-farm activities seem more of a coping mechanism against food insecurity for the poor pastoral community groups than as a means to accumulate wealth and reduce food insecurity by all pastoral community groups. According to the interviews, he made for them, the poor tend to concentrate on off-farm activities characterized by low entry constraints (gathering, charcoal making and fire wood collection and wage). 
According to Yizengaw (2014), revealed that higher the level of the household livelihood diversification, results with, the more food secure of the households. The possible explanation for this as our prior expatiation, diversification of livelihood income sources provides an additional income that enables farmers to spend more on their basic needs include food consumption, education, clothing and health care. Increase in the level of livelihood diversification helps the households to revitalize from different shocks which make farm households food insecure. Besides, Birhanu and Morankar (2010), participation in off-farm activities was found to be significantly and positively associated with food security. Livelihood diversification has been identified as essential strategy for raising income and reducing food insecurity. The level and type of livelihood diversification depends on the accessibility and availability of different livelihood sources. Similarly the status of food security depends on average kcal per day consumed by all members of a household. According to Zerai and Gebreegziabher (2011b) on the study of effect of non-farm income on household food security in eastern Tigrai, Ethiopia to examine the effect of non-farm employment indicates that non-farm employment provides additional income that enables farmers to spend more on their basic needs include food, education, clothing and health care.

Access to non- farm activity (diversification) had found to have significant influence at less than ten percent probability level and positive relation with the food security of household(Gemechu et al,.2016). This shows that, households who have access to non-farm activity have better chance to be food secure than others who have no access to nonfarm activity. Their output of binary logit model indicated that, holding other explanatory variables constant, access of household to nonfarm activity had increase a probability of being food secure by a factor of 3.557 .

\section{Summary and Conclusion}

In Ethiopia, Pastoralists represent approximately $10 \%$ percent of the country population, and approximately $40 \%$ of the land area of Ethiopia is considered to be under pastoral production system (Amare, 2018). Livestock in the pastoral areas are the major source of food (milk and meat) and income, as well as a source of employment. However, the pastoral production system and in particular the food security and livelihood situation is highly threatened because of different man-made and natural risks. The current scenario shows that pastoral livelihood system is seemingly changing due to factors such as recurrent draught and conflict, and other natural and manmade calamities. A study focusing on the future of pastoralism in Ethiopia reads that pastoral households will continue to diversify their sources of income to include waged employment and agriculture where it is feasible, and trading activities as supplements to livestock-based incomes.

Food security is an evolving concept. There are many definitions of food security, which is a clear indication of differing views and approaches to the problem. Formally, food security has been defended as "a situation that exists when people secure access to sufficient amounts of safe and nutritious food for normal growth and development and an active and healthy life. According to this definition, factors that may lead to a situation of food security include availability of food access, proper utilization and stability over a certain time period. In other words, food availability, access, stability and utilization form the four pillars of food security. Therefore, the four pillars must be fulfilled simultaneously in order to realize food security objectives.

Based on duration, food security analysts had classified food insecurity in to two type, which are chronic and transitory. Chronic food insecurity is long-term or persistent, and occurs when people are unable to meet their minimum food requirements over a long period of time. Contrarily, transitory food insecurity is short-term and temporary, and occurs when there is a sudden drop in the ability to produce or access enough food to maintain a good nutritional status. Generally, food security is affected by household head sex, family size, age of household head, educational level of household head, crop production and agricultural technology (use of chemical fertilizer and pesticides, improved seeds), and size of cultivated land, livestock ownership and number, dependency ratio, distance from market center, access to credit and developmental agents visit.

Livelihood diversification is a process by which rural households construct a diverse portfolio of activities and social support capabilities in their struggle for survival and improvement in their standards of living. Livelihood diversification can be classified into three namely on farm, nonfarm and off farm. Livelihood diversification basically influenced by a set of factors in both the area of origin as well as the destination. These factors are routinely referred to as "push" and "pull" factors - or those negative factors that "push" a household out of a given area or lifestyle, and those positive factors that "pull" them into a new location. Specifically, there are different factors that determines pastoral livelihood diversification strategies. Those factors are classified into five types of livelihood assets/capitals, namely, human, financial, social, natural, and physical capital.

In general, higher the level of the household livelihood diversification, results with, the more food secure of the households. This is due to, diversification of livelihood income sources provides an additional income that enables farmers to spend more on their basic needs include food consumption, education, clothing and health care. Increase in the level of livelihood diversification helps the households to revitalize from different shocks which make farm households food insecure. The level and type of livelihood diversification depends on the accessibility and availability of different livelihood sources. Besides, Livelihood diversification has been identified as essential 
strategy for raising income and reducing food insecurity.

\section{Future Prospects}

Based on of this review, the following future prospects were provided to concerned parties [household (individually), government and non-government agents]:

* Education level of households has a strong significant positive relationship with diversification of livelihood options, and food security so as to improve life of households. Therefore, efforts need to be continued in more aggressive manner on training of farmers to improve their knowledge and traditional experiences based on livelihood diversification and food security.

* Family planning and awareness creation for household is too advisable to reduce family size and dependency ratio. Hence, large family size and dependency ratio negatively affects food security.

* Credit service is needed to improve on-farm, off-farm and non-farm activities for livelihood diversification and secure food. Besides, improving production is a center of the current development strategy. Hence, increasing boosting credit access and strengthening the credit institutional support is crucial to make this development possible and improve livelihoods of pastoral households.

* Frequency of contact of development and extension agents for training and advice of households could also be emphasized, since it has significant effect on household's livelihood diversification and food security. Moreover, it improves other associated socio-economic factors.

* Market access should be arranged and established by near with links. Not only market access, but also distance from market center is essential for pastoral households and should be considered by concerned agents to shorten the market distance. Hence, households nearer to market centers had better chances to be food secure and diversify their livelihood than those who are away from market centers due to the reason that households nearer to market center have the probability of selling their produce and purchase food from market easily and timely.

\section{References}

ACAPS (2018). $\quad$ Food $\quad$ insecurity. $\quad$ Retrieved from

https://www.acaps.org/sites/acaps/files/slides/files/20180226_acaps_thematic_report_fo d insecurity final.pdf.

Addisu, Y. (2017). Livelihood strategies and diversification in western tip pastoral areas of Ethiopia. Pastoralism: Research Policy and Practice 7:9 Doi 10.1186/s13570-017-083-3.

Ahmed, A. Azeze, Babiker, M. and Tsegaye, D. (2002). Post-Drought Recovery Strategies among Pastoral Households of the Horn of Africa: A Review. OSSREA, Development Research Report Series no. 3.

Amare, D. and Belaineh, L. (2013). Determinants of income diversification among rural households:

Amare, M. (2018). Determinants of livelihood diversification strategies in Borena pastoralist communities of Oromia regional state, Ethiopia, Dinku Agric \& Food Secur (2018) 7:41.

Asefech, H., and Nigatu, R. (2007). Correlates of household food security in densely populated areas of Southern Ethiopia: Does the Household Structure Matter? J. Home Commun. Sci. 1(2):85-91.

Asfir, S. (2016). Determinants of Rural Households Livelihood Strategies: Evidence from Western Ethiopia. Journal of Economics and Sustainable Development 7(15):103-109.

Barrett, B. and Reardon, T. (2000). Asset, Activity and Income Diversification among African Agriculturalists, Some Practical Issues. Project report to the USAID BASIS CRSP, March 2000.

Barrett, B., Mesfin, B., \& Abdillahi, A. (2001a). Income diversification, poverty traps and policy shocks in Côte d'Ivoire and Kenya. Food Policy, 26(4),367-384. doi:10.1016/S0306-9192(01)00017-3.

Barrett, B., Thomas, R., \& Webb, P. (2001b). Nonfarm income diversification and household livelihood strategies in rural Africa: Concepts, dynamics, and policy implications. Food Policy, 26(4), 315-331. doi:10.1016/S0306-9192(01)00014-8..

Bekele, M., André M., Ayana A., and Anne, Z.(2013). The role of livestock diversification in ensuring household food security under a changing climate in Borana, Ethiopia. Food Sec. Springer Science+Business Media Dordrecht and International Society.

Beruk, Y. (2003). Food Security Situation in the Pastoral Areas of Ethiopia. PP.1-3. National Pastoral Programme Coordinator, Oxfam GB).

Birhanu, Z., Assefa, T., Woldie, M., \& Morankar, S. (2010). Determinants of satisfaction with health care provider interactions at health centres in central Ethiopia: A cross sectional study. BMC Health Services Research, 10(1), 78. doi:10.1186/1472-6963-10-30

Chambers, K. (1995). Sociolinguistic theory. New York: Blackwell..

Debele, B. and Desta, G. (2016). Livelihood diversification: strategies, Determinants and Challenges for Pastoral and Agro-Pastoral Communities of Bale Zone, Ethiopia. International Review of Social Sciences and Humanities 11(2):37-51. 
DFID, (2005). The Role of Relevant Basic Education in Achieving Food Security and Sustainable Rural Development. Emerging Markets Group, Ltd.

Dione, J. (2004). Assuring food and nutritional security in Africa by 2020: A discussion paper for IFPRI. http://www.ifpri.org/event/assuringfood- and-nutrition-security-africa-2020.

Doti, T. (2010). Climate variability, pastoralists' vulnerability and options. The case of the Borana of Northern Kenya. In D. A. Mwiturubani \& J. A. van Wyk (Eds.), Climate change and natural resources conflicts in Africa. Monograph 170. Pretoria, South Africa: Institute for Security Studies.

Dube, A., Jema, H. and Lemma, Z. (2018). Determinants of food insecurity and coping strategies of rural households: The case of Shalla District, West Arsi Zone, Oromia Region, Ethiopia. Journal of development and agricultural economic. Vol. 10(6), pp. 200-212.

Ellis, F. (2000). The determinants of rural livelihood diversification in developing countries. J Agric Econ; 51(2):289-302.

European Union (EU) (2012). Effectiveness of European Union development aid for food security in Sub- Saharan Africa: Special report No. 1, 2012.

FAO (2008). An Introduction to the Basic Concepts of Food Security. Retrieved from. https://europa.eu/capacity4dev/hunger-foodsecuritynutrition/ document/introduction-basic-concepts-foodsecurity

FAO (2018). Global Early Warning - Early Action Report on Food Security and Agriculture. Retrieved from https://reliefweb.int/report/world/global-early-warning-early-actionreport- food-security-and-agriculturejanuary-march-0

Ferro-Luzzi, A.,Morris, S., Taffesse, S., Demissie, T., \& Amato, M. (2001). Seasonal under nutrition in rural Ethiopia. Magnitude, correlates and functional significance. IFPRI Research Report 118. Washington, D.C.

FEWS (Famine Early Warning Systems Network), NET, WFP (2018). Ethiopia Food Security Outlook June 2018 to January 2019. Retrieved from http://fews.net/eastafrica/ ethiopia/food-security-outlook/june-2018.

Feyisa M. (2018). Determinants of food insecurity among rural households of South Western Ethiopia Vol. 10(12), pp. 404-412,

Food and Agriculture Organization and World Food Programme Ethiopia (FAO/WFP) (2012). Special-reportFAO/WFP crop and food supply assessment mission to Ethiopia, Addis Ababa.

Food and Agriculture Organization of the United Nations (FAO) (2004). The state of food insecurity in the world. Rome.

FSIN (2018). Global Report on Food Crises. Retrieved from http://www.fao.org/emergencies/resources/documents/resourcesdetail/ en/c/1107313/

Gecho, Y. (2017). Rural farm households' income diversification: The case of Wolaita Zone, Southern Ethiopia, Social Sciences, Vol. 6(No. 2), 45-56. doi:10.11648/j.ss.20170602.1

Gemechu, F., Lemma Z. and Jemal Y. (2016). Determinants of farm household food security in Hawi Gudina district, West Hararghe zone, Oromia Regional National State, Ethiopia Vol.8(2), pp. 12-18.

Genene, T. and Wegayehu, B. (2010). Farmers` perceptions of land degradation and determinants of food security at Bilate Watershed, South Ethiopia. EJAST 1(1):49-62.

Goal Ethiopia (2017). Factors for households exiting agro-pastoral livelihoods and an assessment of the urban livelihood opportunities in borena zone, Ethiopia. Pp.1-40.

Grace, C. (2000). Livelihood diversification in southern Ethiopia. Institute of developmental studies, pp 3-33.

Gulled, A. (2006). Food Insecurity and Coping Strategies of Agro-Pastoral Households in Awbare Woreda, Somali Region Ethiopia. An M.sc Thesis Presented to the School of Graduate Studies of Haramaya University. 63p.

Hilina M. (2005). Dimensions and Determinants of Poverty in Pastoral Areas of Eastern Ethiopia: The Case of Shinile Zone in Somali National Regional State. An M.sc Thesis Presented to the School of Graduate Studies of Haramaya University. 90p.

IFRC (2018). IFRC Situation Report: Regional Food Crisis in Africa - 18 January 2018. Retrieved from http://ifrcgo.org/foodsecurity/img/Africa-Food-Crisis-SitRep14.pdf

Indris, S. and Adam B. (2013). Assessment of Food Insecurity and Coping Mechanisms among Pastoral Households of Afar National Regional State: The Case of Chifra District, Ethiopia Ethiop. J. Agric. Sci. 23:145-156.

Ingawa, A. (2002). Keynote address at the 8th Annual conference of the agricultural extension society of Nigeria held in Benin City, 16-19 September. Processing of the Agricultural Extension Society of Nigeria.

Jebessa T. and Zelalem, B. (2014). Literature Review Report on Understanding the Context of People Transitioning out of Pastoralism (TOPs) in Ethiopia, Haramaya University, pp 7-31.

Jrad, S., Nahas, B., \& Baghasa, H. (2010). Food security models. Ministry of agriculture and agrarian reform, national agricultural policy center. Policy Brief, 33, 32. Syrian Arabic Republic.

Kassie, G., Kim, S., Francisco, P., Fellizar, J. (2017). Determinant factors of livelihood diversification: Evidence from Ethiopia. Cogent Social Sciences 3:1369490. https://doi.org/10.1080/23311886.2017.1369490. 
Kassie, W., Aye, G. (2017). The Nexus between livelihood diversification and farmland management strategies in rural Ethiopia. Cogent Econ Finance.; 5(1):1275087.

Mengistie, D. and Kidane, D. (2016). Assessment of the Impact of Small-Scale Irrigation on Household Livelihood Improvement at Gubalafto District, North Wollo, Ethiopia. Agriculture 6:27. Doi: 10.3390/agriculture 6030027.

Mutisya, M., Ngware, M., Kabiru C., and Kandala, N. (2016). The effect of education on household food security in two informal urban settlements in Kenya: a longitudinal analysis. Food security pp. 743-756.

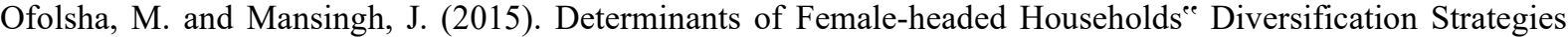
Choice in Ambo District, Ethiopia. Journal of Extension Education 27(2):5424-5430.

Plan for Accelerated and Sustainable Development to End Poverty (PASDEP) (2005). Building progress-a plan for accelerated and sustainable development to end poverty: Volume I, Main Text. Addis Ababa, Ethiopia.

Regassa, N., \& Stoecker, J. (2012). Household food insecurity and hunger among households in Sidama district, Southern Ethiopia. Public Health Nutrition, 15, 1276-1283.

Sanusi, R., Badejo, C., \& Yusuf, O. (2006). Measuring household food insecurity in selected local government areas of Lagos State and Ibadan, Nigeria. Pakistan Journal of Nutrition, 5, 62-67. doi:10.3923/pjn.2006.62.67

Shiferaw, F., Richard L., Christy, G. (2003). Determinants of food security in southern Ethiopia. Food and resource Economics Department of Institute of Food and Agricultural Science, University of Florida.

Tesfaye, L. (2003). Livelihood strategies in context of population pressure. A case study in Hararghe Highlands, East Ethiopia. Ph. D. Dissertation. University of Pretoria. South Africa.

USAID. (2008). Madagascar Food Security Development programming Framework, From the American People. Madagascar: United States Agency International Development.

WFP, FAO (2008). Journal of Rural Studies, Retrieved April 52009. Retrievedfrom: http://www.answers.com/topic/ income?cat=biz-fin.

Yizengaw, B. (2014). Determinants of Household Income Diversification and Its Effect on Food Security Status in Rural Ethiopia: Evidence from Ethiopia Longitudinal Rural Household Survey. (Doctoral dissertation, Master's thesis, Addis Ababa University, Addis Ababa, Ethiopia).

Zakari, S. Ying, L. Song, B. (2014). Factors Influencing Household Food Security in West Africa: The Case of Southern Niger. Sustainability pp. 1191-1202.

Zerai, B., \& Gebreegziabher, Z. (2011b). Effect of nonfarm income on household food security in Eastern Tigrai. Ethiopia: An Entitlement Approach. Food Science and Quality Management Vol 1, pp 1-22. 